\title{
KOMUNIKASI SOSIAL PELAKU AMORAL TERHADAP MAKNA AGAMA
}

\author{
Agoes Moh. Moefad \\ Dosen Tetap Program Studi IImu Komunikasi Fakultas Dakwah IAIN Sunan \\ Ampel Surabaya
}

\begin{abstract}
Abstraksi
Maraknya kasus penipuan, pengingkaran janji, perusakan hak milik orang lain, mencelakakan orang lain dengan kekerasan fisik, pembunuhan, perkosaan dan perzinaan merupakan bukti nyata hancurnya derajat manusia yang memiliki nilai kemanusiaan universal. Ajaran agama mengandung klaim kebenaran yang bersifat universal, ini memungkinkan terjadinya ambiguitas interpretasi menurut tingkat pemahaman, penghayatan, dan moralitas spiritual penganutnya. Untuk itu, untuk menghindari perbedaan makna untuk mewujudkan kedamaian sosial masyarakat merupakan nilai universal. Dengan nilai ini, semua manusia melalui agamanya diharapkan dapat hidup secara damai, menghormati, toleransi dan bekerja sama dalam permasalahan sosial
\end{abstract}

Kata Kunci: Agama, Amoral, Sosial.

\section{Latar Belakang}

Dorongan beragama merupakan dorongan psikis yang mempunyai landasan alamiah dalam watak kejadian manusia. Dalam relung jiwa manusia merasakan adanya suatu dorongan untuk mencari serta memikirkan sang pencipta. Al-quran menyatakan bahwa dorongan beragama merupakan dorongan alamiah : "Maka hadapkanlah wajahmu dengan lurus kepada agama (Allah); (tetaplah atas) fitrah Allah yang telah menciptakan manuia menurut fitrah itu, tidak ada perubahan pada fitrah Allah. (itulah) agama yang lurus; tetapi kebanyakan manusia tidak mengetahui". (QS. Ar-Rum: 30) ${ }^{1}$

Dalam ayat ini Allah mengemukakan bahwa dalam fitrah manusia, yakni dalam penciptaan dan tabiat dirinya sudah terdapat kesiapan alamiah. ${ }^{2}$

\footnotetext{
${ }^{1}$ Al-Qur'an dan Terjemahan, Departemen Agama Republik Indonesia

${ }^{2}$ Najati, Utsman, Al-Qur'an dan Ilmu Jiwa Agama, (Bandung: Penerbit Pustaka, 2000), hal. 69.
} 
Berbagai faktor yang membangkitkan dorongan beragama dalam diri manusia ialah berbagai bahaya yang mengancam kehidupan, menutup semua pintu keselamatan, dan tiada jalan lain untuk berlindung kecuali pada Allah. Maka dengan dorongan alamiah yang dimilikinya itu, ia pun kembali pada Allah guna meminta pertolongan keselamatan kepada Nya dari berbagai bahaya yang mengancam. Adapun motif seseorang berkelakuan religius menurut Syukur ${ }^{3}$ adalah: untuk mengatasi frustasi, untuk mmenjaga kesusilaan serta tata tertib masyarakat, untuk memuaskan intelek yang ingin tahu, serta untuk mengatasi ketakutan.

Psikologi mengobservasi bahwa keadaan frustasi dapat menimbulkan perilaku keagamaan. Orang yang mengalami frustasi, tak jarang mulai berkelakuan religius.

Agama manapun selalu menghadirkan manusia dalam eksistensinya yang paling mulia diatas semua jenis makhluk, yakni dimilikinya peradaban dalam kehidupan manusia. Peradaban dengan memberikan peluang pada seluruh manusia untuk hadir sebagai manusia, bukan binatang. Karena hanya agama yang mampu memberikan kode etik yang bernilai absolut untuk mengangkat martabat manusia dan membedakannya dengan makhluk lain.

Dalam perjalanan sejarah, manusia yang telah dikaruniai Tuhan dengan indera pendengar, penglihatan dan sebagainya sering kali berprilaku melawan kodrat. Manusia tidak lagi berpijak pada kebenaran nurani dan akal sehat sehingga tindakan-tindakannya jauh dari keinginan Tuhan, jauh dari norma agama yang diturunkan untuk membangaun peradaban manusia. Padahal, dimana ketika telah tidak ada lagi yang mengikuti norma-norma agama dan norma sosial, maka dia telah tergelincir pada lubang yang sesak dan menyesatkan yang dibuatnya sendiri.

Maraknya kasus penipuan, pengingkaran janji, perusakan hak milik orang lain, mencelakakan orang lain dengan kekerasan fisik, pembunuhan, perkosaan dan perzinaan merupakan bukti nyata hancurnya derajat manusia yang memiliki nilai kemanusiaan universal.

Agama hanya menjadi sebuah pilihan, disaat akan membutuhkan dia akan memilihnya, dan barang siapa yang tidak atau belum merasa butuh tidak akan mengambilnya sebagai pedoman hidup (way of life) baik untuk sementara waktu, bahkan bisa juga untuk selama-lamanya.

Agama akan berubah wujud menjadi semacam fashion dan barang belanjaan, banyak tawaran sesuai selera pembeli dan penikmat asalkan dapat memberikan kepuasan dalam hidupnya. Jika dalam hidup merasa puas dengan agama lain yang menjanjikan kesejahteraan dalam hidupnya sangat mungkin konversi agama akan terjadi.

\footnotetext{
${ }^{3}$ Nico Syukur, Pengalaman dan Motivasi Beragama, (Jakarta: Kanisius, 1988), hal. 74.
} 
Realita yang ada, fenomena perkosaan dan perzinahan seakan menjadi fenomena biasa, bukanlah hal yang tabu. Didalam interaksi sosial sehari-hari (sistem sosial), sering terjadi beberapa beberapa gejala yang cenderung mendorong perilaku amoral, misalnya; adanya diskriminasi, segregasi, arogansi dari lingkungan.

Pada sisi lain, waktu interaksi antara anak dengan orang tua semakin pendek, sementara waktu interaksi anak dengan sesamanya (peer group) semakin panjang dan intens, sehingga solidaritas pada peer group bisa jauh lebih berpengaruh daripada nasihat atau harapan orang tua. Kontrol sosial yang serba lemah, sehingga banyak masyarakat lebih memilih sikap egois, kurang peduli terhadap kemunkaran yang terjadi.

Fenomena macam ini tampaknya sudah menjadi bagian dari potret kehidupan saat ini. Dalam komunitas masyarakat religius (pelaku ibadah mahdhoh) tampak sekali ibadah dilaksanakan hanya sekedar "formalitas" tanpa memahami makna dibalik itu, artinya hanya sekedar "menggugurkan" kewajiban, sedangkan unsur "kualitas" yang menyebabkan ibadah itu syah atau tidak, kurang diperhatikan. Larangan-larangan yang tersirat dalam ajaran agama seperti; perzinaan, perjudian, minum-minuman keras dan lain sebagainya mewarnai kehidupan sehari-hari mereka. Ajaran agama pada komunitas ini tetap dijalankan, akan tetapi perbuatan yang asusila tetap mereka lakukan.

Ajaran agama mengandung klaim kebenaran yang bersifat universal, ini memungkinkan terjadinya ambiguitas interpretasi menurut tingkat pemahaman, penghayatan, dan moralitas spiritual penganutnya. Untuk itu, untuk menghindari perbedaan makna untuk mewujudkan kedamaian sosial masyarakat merupakan nilai universal. Dengan nilai ini, semua manusia melalui agamanya diharapkan dapat hidup secara damai, menghormati, toleransi dan bekerja sama dalam permasalahan sosial.

Untuk memahami nilai agama dalam aplikasi kehidupan sosial, maka perlu melihat pola komunikasi yang terjadi pada diri manusia dengan melihat kondisi, situasi dan prasyarat komunikasi tertentu. Jurgen Habermas menegaskan bahwa dengan memahami komunikasi sebagai dimensi praksis manusia, teori tindakan komunikasi dapat memberikan landasan bagiterselenggaranya komunikasi yang ideal yang didasarkan pada rasional komunikatif. Dalam konteks ini, makna agama menyangkut anggapan normatif dari interaksi sosial, yaitu dimensi komunikasi perbincangan rasional dalam komunikasi sosial yang mencakup psikologi sosial yang berkaitan dengan aspek kualitas norma, budaya, moral dalam hubungannnya dengan interaksi sosial.

Atas dasar penjelasan di atas, peneliti memandang perlu menetapkan untuk meneliti tentang "Komunikasi Sosial Pelaku Amoral Masyarakat Kauman Mojosari Mojokerto Terhadap Makna Agama". 
Komunikasi Sosial Pelaku Amoral Terhadap Makna Agama | 81

Jurnal Ilmu Komunikasi, Vol. 1, No.1, April 2011

ISSN: 2088-981X 


\section{Rumusan Masalah}

Masalah yang diangkat adalah bagaiamana tindakan komunikatif diletakan sebagai landasan komunikasi sosial pelaku amoral masyarakat Kauman Mojosari Mojokerto dalam memaknai agama. Dengan demikian penelitian ini meletakan nilai pola komunikasi sebagai landasan komunikasi sosial yang ideal didasarkan pada rasionalitas yang komunikatif.

\section{Komunikasi Sosial}

Berbicara pada lingkup sosial, maka interaksi maupun komunikasi yang dilakukan pun akan bersifat sosial. Dalam hal ini Sigman (1987:4) mengatakan, "Communication in this view is seen not as individual phenomenon but as a societal-level one". Dari sini menjadi jelas bahwa komunikasi sosial merupakan sebuah kegiatan yang bergerak pada ranah sosial sebagai indikasi yang terlahir akibat terbentuknya sebuah interaksi sosial.

Menurut Sigman komunikasi bukan merupakan fenomena individual tetapi sebagai bentuk bermasyarakat (Sigman, 1987). Dari sini menjadi jelas bahwa komunikasi sosial merupakan kegiatan komunikasi ranah sosial untuk yang merupakan fenomena dari kehidupan bermasyarakat.

Komunikasi sosial, merupakan kegiatan komunikasi yang ditujukan untuk menyatukan komponen-komponen sosial yang bervariasi dan mempunyai perilaku berbeda-beda (Sigman, 1987). Sehingga komunikasi sosial menjadi penting kedudukannya sebagaimana dijelaskan oleh Habermas yang menekankan perlunya "dibangun kondisi komunikasi yang menjamin sifat umum norma-norma yang dapat diterima dan menjamin otonomi warga melalui kemampuan emansipatoris, sehingga menghasilkan proses pembentukan kehendak bersama lewat perbincangan."

Komunikasi sosial, melihat dari beberapa pendapat diatas mempunyai elemen seperti aktivitas komunikasi, masyarakat, konsensus dalam masyarakat, kegiatan pertukaran pengalaman antar anggota masyarakat atau interaksi (Sigman, 1987)

\section{Amoral \& Agama}

Amoral atau tuna susila berasal dari dua kata, yaitu tuna yang berarti tidak mempunyai dan susila yaitu tata krama, sopan santun atau adab. ${ }^{4}$

Menurut makna istilah adalah semua perbuatan yang tidak mempunyai susila, yakni kriminalitas yang dalam definisinya adalah semua kejahatan yang mencakup seluruh gejala patologi sosial (pelacuran, narkotik, perjudian $\mathrm{dII})^{5}$

\footnotetext{
${ }^{4}$ Dahlan Ya`cub, Kamus Bahasa Indonesia Kontemporer. (Semarang: Pustaka Ilmu, 1996), hal 60.
} 
Perilaku tuna susila atau prilaku amoral dalam masyarakat jawa dikenal istilah "mo-limo" (tidak mau terhadap lima macam prilaku). Jadi yang dimaksud dengan prilaku tuna susila adalah masyarakat yang melakukan aktifitas lima prilaku yang tidak sesuai dengan norma, yakni; perzinahan, perjudian, narkotika, minuman keras dan pencurian.

a. Pelacuran

Menurut Bonger pelacuran ialah gejala kemasyarakatan dimana wanita menjual diri melakukan perbuatan-perbuatan seksual sebagai mata pencaharian. $^{6}$

Termasuk dalam pembahasan ini adalah lelaki hidung belang atau bisa disebut dengan gigolo. Pembahaan ini lebih meluas dengan menjabarkan masalah perzinahan, artinya perilaku seks tidak hanya dijadikan sebagai mata pencaharian, akan tetapi dilakukan atas dasar suka sama suka.

b. Narkotik

Narkotik (narcotics=obat bius) adalah semua bahan obat yang mempunyai efek kerja yang bersifat membiuskan, menurunkan kesadaran (deppresant), merangsang meningkatkan prestasi (stimulans), menagihkan ketergantungan (dependence), menghayalkan (halusinasi).

c. Perjudian

Perjudian adalah pertaruhan dengan sengaja ; yaitu mempertaruhkan satu nilai atau sesuatu yang dianggap bernilai, dengan menyadari adanya risiko dan harapan-harapan tertentu pada peristiwa-peristiwa permainan, pertandingan, pelombaan dan kejadian-kejadian yang tidak atau belum tentu hasilnya.

\section{Bentuk-bentuk perjudian}

1. Bentuk-bentuk permainan dan undian yang legal, dengan izin pemerintah

2. Bentuk permainan dan undian yang illegal ${ }^{7}$

d. Pencurian

Mencuri adalah mengambil harta orang lain dengan jalan diam-diam, diambil dari tempat penyimpanannya. ${ }^{8}$

e. Minuman Keras

Semua jenis minuman yang memabukkan, baik diminum sedikit atau banyak, seperti: arak, anggur dan sebagainya. ${ }^{9}$

\footnotetext{
${ }^{5}$ Simandjuntak B, Patologi Sosial, (Jakarta: PT Gramedia, 2001), hal. 3.

${ }^{6}$ Kartini Kartono, Patologi Sosial, (Jakarta: Rajawali Press, 1991), hal. 119.

${ }^{7}$ Ibid, hal. 55.

${ }^{8}$ Rasyid Sulaiman, Fiqh Islam, (Cet. 33; Yogyakarta: Sinar Baru Al-Gresindo, 2000), hal. 440.

${ }^{9}$ Ibid, hal 236.
} 
Sebagaimana yang dikatakan oleh David, Makna menurut arti bahasa adalah arti atau maksud suatu kata. Secara istilah adalah; kemampuan total untuk mereaksikan terhadap bentuk linguistik.

Sedangkan kata "agama" menurut arti bahasa berasal dari dua kata yaitu: "a" artinya tidak dan "game" artinya pergi. Agama berarti tidak pergi, tetap ditempat, diwarisi secara turun temurun. ${ }^{10}$ Sedangkan pengertian yang lain artinya: keyakinan atau kepercayaan terhadap Tuhan. ${ }^{11}$

Menurut pengertian istilah, sebagaimana ditulis Bellah ${ }^{12}$ yaitu, kebaktian pemisahan antara sakral dan profan, kepercayaan terhadap jiwa, kepercayaan terhadap dewa-dewa atau Tuhan, penerimaan atas wahyu yang supranatural, dan pencarian keselamatan.

Agama adalah ajaran yang mengandung kewajiban-kewajiban yang harus ditunaikan kepada Allah, kewajiban untuk dirinya sendiri dan kewajiban kepada sesama manusia serta kewajiban kepada semua mahkluk hidup lainnya. ${ }^{13}$

Dari keterangan termaktub diatas dapatlah dirumuskan sebuah definisi bahwa agama adalah suatu sistem credo (tata keyakinan) atas adanya yang mutlak diluar manusia, atau sistem retus (sistem peribadatan) manusia kepada yang dianggapnya yang mutlak itu, serta satu sistem norma (tata kaidah) yang mengatur hubungan manusia dengan sesama manusia dan dengan alam lainnya.

\section{Kerangka Teori}

Jurgen Habermas menyatakan syarat mencapai komunikasi adalah dipenuhinya prasyarat komunikasi, seperti pelaku komunikasi yang mencapai kesadaran moral otonom, memegang prinsip etika universal, memperhatikan setiap pola tindakan yang dilakukan, menciptakan kondisi dan situasi pembicaraan ideal dengan mengatasi segala macam hambatan, dan kemungkinan distorsi yang terjadi dalam komunikasi.

Komunikasi sosial merupakan suatu bentuk komunikasi dan bagian penting untuk terbentuknya masyarakat komunikatif, menurut Zimmermann ${ }^{14}$

\footnotetext{
${ }^{10}$ Nata, Abudin, Metodologi Studi Islam, (Jakarta: PT. Raja Grafindo Persada, 1999), hal. 9.

11 Dahlan Ya'cub, Kamus Bahasa Indonesia Kontemporer, (Jakarta: PT. Raja Grafindo Persada, 2003), hal. 39.

12 Robert N Bellah, Religi Tokugawa; Akar-Akar Budaya Jepang, diterjemahkan oleh Wardah Hafidz dan Wiladi Budiharga, (Jakarta: Gramedia Pustaka Utama, 1992), hal 187.

${ }^{13}$ Abdul Jabar Adlan, Dirasah Islamiyah, (Surabaya: IAIN Sunan Ampel Press, 1995), hal, 14.

${ }^{14}$ Menurut Zimmermann, Habermas melintasi Karl Marx karena pemikirannya mengeni "skema sosialisasi kepribadian" yang tidak ada dalam Marx. Skema yang ada pada karyakarya awal Habermas itu merupakan konsep politik tentang "suatu diskusi yang bebas
} 
perlu dibentuk forum komunikasi, ruang publik yang demokratis, bebas dari dominasi dan hegemoni satu pihak, di mana pelaku-pelaku kesadaran yang terbuka, matang, dan kritis dapat berperan dan mengambil bagian dalam komunikasi yang interaktif.

Dalam teori tindakan komunikatif, etika-moral yang bersifat rasionalpraktis di mana kategori-kategori yang bersifat imperatif dengan klaim normatif-universal diharapkan dapat mendasari interaksi masyarakat. Teori tindakan komunikatif ini menguraikan struktur keputusan moral yang diungkapkan melalui teori psikologi sosial moral (theory of the social psychology of moral), baik dalam tahapan moral Laurence Kohlberg maupun Jean Piaget dan menghubungkannya ke dalam struktur interaksi sosial melalui prosedur argumentasi moral dalam pencapaian kesalingmengertian persetujuan yang rasional. ${ }^{15}$

Komunikasi sosial pelaku amoral merupakan bagian penting dari suatu bentuk proses komunikasi dalam mencapai cita-cita sosial masyarakat yang komunikatif. Cita-cita sosial masyarakat yang komunikatif itu berjalan secara evolusi berdasarkan proses belajar peran sosial dari kesadaran pelaku tindakan komunikatif.

\section{Metode Penelitian}

Penelitian ini menggunakan paradigma penelitian kualitatif sebab dalam penelitian ini peneliti menggunakan pendekatan fenomenologis ${ }^{16}$, peniliti berusaha memahami arti peristiwa dan dalam kaitannya dalam situasi-situasi tertentu pada pola komunikasi sosial pelaku amoral.

Metode penelitian kualitatif ini dengan melakukan pengamatan partisipatoris, wawancara yang mendalam, melakukan analisis dari kelompok yang kecil serta memahami keadaan sosial yang terjadi. Maka hasil dari metode ini diharapkan dapat diinterpretasikan mengenai "makna" dari gejala-gejala yang terjadi.

Fenomenologi menempatkan tindakan dalam pikiran. Fenomenologi dipakai dalam berbagai kajian pada bidang ilmu, termasuk ilmu komunikasi sebagai bagian dari ilmu sosial. Pokok pikiran Alfred Schutz menurut Ferguson

dominasi". Rolf Zimmermann, "Emancipation and Rationality: Foundational Problems in the Theories of Marx and Habermas", dalam Ratio, XXXVI, 1984, hlm. 2.

15 Jürgen Habermas, Moral Consciousness and Communicative Action, trans. Christian Lenhardt dan Shierry Weber Nicholsen (Cambridge: The MIT Press, Massachussett, 1990), hlm. 116-195.

16 Moleong, J. Lexy, Metodologi Penelitian Kualitatif, (Cet.7; Bandung: PT.Remaja Rosdakarya, 2002), hal. 9. 
(2001; 244) terhadap fenomenologi adalah analisisnya dalam kesadaran dunia intersubyektif dan pengalaman penuh dengan makna.

Schutz menekankan bahwa perilaku manusia tidak dapat dimengerti bahkan dipahami jika tidak memperhatikan pemaknaan individu yang melekat pada pengalaman dan perilaku manusia, budaya dapat menjadi sumber utama dalam pemaknaan. Tugas fenomenologi, menurut Schutz, adalah menghubungkan antara pengetahuan ilmiah dengan pengalaman sehari-hari dan dari kegiatan dimana pengalaman dan pengetahuan berakar (Craib, 1986: 126 disarikan oleh Sukidin, 2002: 39).

Menurut Husserl, fenomenologi menggunakan intuisi sebagai sarana untuk mencapai kebenaran. Beberapa kata kunci Husserl adalah :

a. Fenomena adalah realitas esensi, dalam fenomena tercakup pula
b. Penomenamatan adalah aktifitas spiritual atau rohani.
c. Kesadaran adalah sesuatu yang intensional (terbuka dan terarah pada
objek)

d. Substansi adalah kongkrit yang menggambarkan isi dan struktur kenyataan dan sekaligus bisa terjangkau (Campbell, 1994: 232)

Fenomenalogi Husserl, secara garis besar mencakup dua langkah utama, pertama; pembedaan atas realitas natural dan realitas eiditik. Kedua; pembedaan antara esensi imanen dengan esensi transenden. Esensi transenden meliputi esensi-esensi semacam "benda", "bentuk khusus", "gerakan", "warna sesuatu", dan lain sebagainya (Bachtiar, 2006, hal; 143).

Sedangkan, L.Peter Berger, menyumbangkan pemikirannya untuk pengembangan fenomenologi yaitu menggabungkan analisis yang bersifat menyeluruh/holistic dan individualistic. Berger ingin melihat makna yang berkembang diluar makna umum: bahwa manusia mempunyai naluri yang stabil dan bersifat khusus. Menurutnya, makna yang berkembang dalam organisasi sosial mengalami objektivitas di dalam institusi-institusi sosial dan karena itu mensosialisasi anggota baru dari suatu komunitas. Ide, nilai kultural, dan norma, dilihat sebagai pusat organisasi sosial yang didalamnya anggota-anggota baru disosialisasikan. Namun, Berger lebih menempatkan perkembangan nilai dan norma di luar dari interaksi sosial dari individu-individu, fenomenologi menempatkan tindakan dalam pikiran.

Penelitian dengan pendekatan fenomenologis adalah berusaha untuk memahami makna peristiwa serta interaksi pada orang-orang dalam situasi tertentu. Pendekatan ini menghendaki adanya sejumlah asumsi yang berlainan dengan cara yang digunakan untuk mendekati perilaku orang dengan maksud menemukan "fakta" atau "penyebab". 
Kebenaran ilmiah menurut paradigma ini tidak bersifat nomotetik melainkan bersifat ideografik, yaitu mengungkap secara naratif dengan memberikan uraian rinci mengenai hakekat suatu obyek atau konsep. Kebenaran itu juga bersifat unik dan hanya dapat ditransfer bila kondisi dan situasinya sama. Maka hasil yang dimunculkan sebagai kebenaran ilmiah pada penelitian ini merupakan hasil analisis yang berupa naratif.

Penelitian ini bukan merupakan uji teori tetapi penggunaan tori yang dikaitkan dengan fenomena yang ada, yang akhirnya peneliti mengambil penemuan baru yang berupa konsep dari objek penelitian. Dengan kata lain penelitian ini tidak dimulai dari deduksi teori tapi dimulai dari fakta empiris. ${ }^{17}$

Dalam penelitian ini yang menjadi informan adalah pelaku amoral di masyarakat Kauman Mojosari Mojokerto serta orang-orang yang mengerti dan paham mengenai focus penelitian ini untuk dapat memberikan informasi/keterangan mengenai situasi dan kondisi latar belakang penelitian.

Dari data yang terkumpul kemudian dianalisa. Analisis data merupakan proses mengorganisasikan dan mengurutkan data kedalam pola, kategori dan satuan uraian dasar sehingga dapat ditemukan tema dan dapat dirumuskan menjadi teori subtansif.

Langkah-langkah analisis data, terdiri atas tiga komponen tahapan, yaitu: reduksi data, penyajian data dan penarikan kesimpulan.

1. Reduksi data merupakan proses pemilihan, pemusatan perhatian, pengabstrakan dan transformasi data kasar yang muncul dari catatancatatan tertulis. $^{18}$

2. Penyajian data, sebagai kumpulan informasi tersusun yang memberikan kemungkinan adanya penarikan kesimpulan dan pengambilan tindakan. ${ }^{19}$

3. Penarikan kesimpulan, dari dua tahap diatas tentunya telah memberikan sumbangan arahan bagi penyimpulan. Sejak awal pengumpulan data, peneliti sudah berupaya memahami mana data yang ditentukan, melakukan pencatatan secara teratur, menentukan pola, menentukan pertanyaan-pertanyaan, memahami hubungan sebab akibat dan sebagainya, tentunya yang terkait dengan focus penelitian ini.

Ketiga analisa data tersebut, baik reduksi data, penyajian data maupun penarikan kesimpulan atau verifikasi merupakan langkah yang jalin-menjalin pada saat sebelum, selama ataupun setelah pengumpulan data sebagai suatu bagian-bagian yang sejajar. Oleh karena itu, ketiga langkah analisa dan

\footnotetext{
17 Margono. S, Metode Penelitian Pendidikan, (Jakarta: PT.Rineka Cipta, 1997), hal 38.

${ }^{18}$ Milles, Mattew B. dan.A. Michael Huberman, Analisis Data Kualitatif (Jakarta: Penerbit Universitas Indonesia, 1992), hal. 16.

${ }^{19}$ Patton Quinn Michael, Qualitative Evolution Methods, (London: Sage Publication, 1987), p. 132.
} 
pengumpulan data merupakan suatu siklus atau proses yang interaktif. Bagaimana proses analisa data penelitian tentang "Komunikasi Sosial Pelaku Amoral Terhadap Makna Agama", dapat dilihat pada bagan berikut :

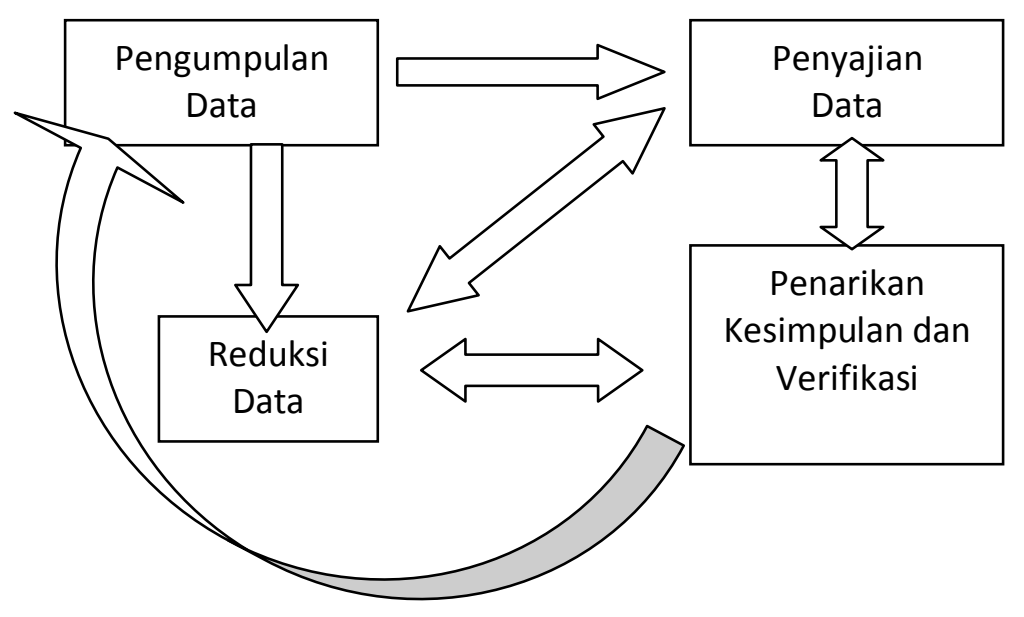

Model Analisis Data (Model Interaktif, Miles dan Huberman) ${ }^{20}$

\section{Tehnik Pemeriksaan Keabsahan Data}

Keabsahan data merupakan konsep penting yang diperbaharui dari konsep kesahian (validitas) dan kehandalan (realibilitas) menurut versi positivisme dan disesuaikan tuntutan pengetahuan, kriteria dan paradigmanya sendiri. ${ }^{21}$ Untuk melakukan pemeriksaan keabsahan data tentang komunikasi sosial pelaku amoral masyarakat Kauman Mojosari Mojokerto, digunakan langkah-langkah sebagaimana yang dikemukakan oleh Lincoln dan Guba.

Langkah pemeriksaan keabsahan data ini peneliti lakukan sesuai dengan kebutuhan dan permasalahan yang didapat selama pengumpulan data. Namun, jika seandainya dengan satu atau dua langkah saja keabsahan data sudah dapat dipertanggungjawabkan, langkah yang lainnya tidak peneliti lakukan. Langkah-langkah sebagaimana yang dikemukakan oleh Lincoln dan Guba (1981) adalah :

\footnotetext{
${ }^{20}$ Milles, Mattew B. dan.A. Michael Huberman, Analisis Data Kualitatif (Jakarta: Penerbit Universitas Indonesia, 1992), hal. 125

${ }^{21}$ Lexy Moleong, Metodelogi Penelitian Kualitatif, (Bandung: Remaja Rosda Karya, 2004), hal 187.
} 
a. Activities in creasing the probability that credible finding will be produced.

Perpanjangan keikutsertaan, peneliti akan mempelajari budaya atau kondisi latar belakang penelitian sehingga dapat menguji ketidakbenaran informasi yang digali, baik dari diri sendiri maupun subjek penelitian, hal ini dimaksudkan untuk membangun kepercayaan subjek.

Perpanjangan penelitian juga memberikan manfaat untuk melakukan orientasi dengan situasi guna memastikan apakah konteks itu dapat dipahami dan dihayati. Dengan kata lain, perpanjangan keikutsertaan ini berguna untuk menghindari distorsi informasi yang berasal dari peneliti ataupun informan, jangan sampai informan dusta atau pura-pura ketika memberikan informasi.

b. Persistence Observation.

Ketekunan pengamatan merupakan upaya peneliti untuk menemukan dan memusatkan perhatian pada unsur-unsur yang diteliti sehingga dapat mencapai suatu penelaahan yang mendalam tentang komunikasi sosial pelaku amoral terhadap makna agama.

\section{c. Triangulation}

Empat macam triangulasi sebagai tehnik pemeriksahan keabsahan data, yaitu; memanfaatkan penggunaan sumber, metode, penyidik dan teori. Memanfaatkan keempat macam triangulasi itu secara jelas dikemukakan oleh Patton ${ }^{22}$. Pada dasarnya triangulasi merupakan upaya untuk melakukan pengecekan data, baik dengan cara membandingkan (misalnya; data hasil pengamatan dengan data hasil wawancara), pengecekan kembali data yang diperoleh dengan tehnik yang sama, pengecekan dengan menggunakan penyidik atau pengamat lain, atau dengan melakukan pengecekan banding (rival explanation). Dengan menggunakan tehnik triangulasi ini, data tentang komunikasi sosial pelaku amoral masyarakat Kauman Mojosari Mojokerto yang telah dikumpulkan selalu akan dicek kembali atau dibandingkan seperti yang telah diuraikan diatas.

\section{d. Peer debriefing}

Tehnik ini dijelaskan dengan cara menjelaskan hasil sementara penelitian tentang komunikasi sosial pelaku amoral masyarakat Kauman Mojosari Mojokerto dalam bentuk diskusi dengan teman-teman sejawat. Kejujuran dan keterbukaan peneliti penting sekali dalam pemeriksahan keabsahan data dalam tehnik ini. Dari diskusi inilah peneliti mungkin bisa melakukan

22 Michael Quinn Patton, Qualitative Evaluation Methods, (London: Sage Publications, 1987), hal 331 
pengecekan kembali kalau ternyata ada data yang tidak cocok atau melenceng dari focus penelitian.

e. Referential adequacy

Kecukupan referensial ini bertujuan untuk membandingkan data tentang komunikasi sosial pelaku amoral masyarakat Kauman Mojosari Mojokerto yang diperoleh dengan kritik yang telah terkumpul. Dalam melakukan pengujian keabsahan data, hasil rekaman maupun foto merupakan alat penting untuk pembanding.

\section{f. Negative case analysis}

Tehnik ini merupakan upaya mengumpulkan contoh dan kasus yang tidak sesuai dengan pola dan kecenderungan informasi yang telah dikumpulkan sebagai bahan pembanding. Dengan demikian, tehnik ini bermanfaat untuk lebih memperkuat argumentasi penemuan dalam penelitian tentang komunikasi sosial pelaku amoral masyarakat Kauman Mojosari Mojokerto.

\section{Komunikasi Sosial Pelaku Amoral}

Pelaku Amoral pada umumnya melaksanakan kewajiban-kewajiban ajaran agama, karena mereka menyadari bahwa dirinya masih membutuhkan ketenangan yang tidak dapat diperoleh ataupun dibeli dengan materi, mereka mengakui adanya yang ghaib. Dengan menjalankan kewajiban agama dirinya merasa menjadi suci dan bersih dari dosa.

Situasi yang "menyuruhnya" berbuat demikian, karena nilai sosial dan budaya masyarakat Kauman masih tampak religius. Setelah mereka berbuat amoral, ketika datang waktu shalat mereka juga mneyempatkan diri untuk membersihkan dosanya. Singkatnya mereka menjalankan kewajiban agama, akan tetapi larangan-larangan yang tersirat dalam ajaran agama tetap mereka lakukan.

Kegiatan keagamaan yang diadakan tidak jauh beda dengan kegiatan keagamaan pada umumnya. Pelaku amoral juga ikut berperan aktif dalam menyemarakkan kegiatan kegamaan dengan berbagai bentuk, ada yang menyumbang konsumsi meski tidak menghadiri, ada yang menghadiri sebagi bukti kepedulian terhadap kegiatan yang diadakan.

Para pelaku amoral sebenarnya tidak menginginkan perbuatannya berakibat atau terwarisi oleh anak cucu. Anak-anak mereka dididik menurut ajaran agama dengan menyekolahkan anak-anak mereka ke TPQ dengan harapan kelak saat orang tuanya (pelaku amoral) meninggal ada yang mendoakan.

Manusia pada hakikatnya tidak berharap dirinya terjerumus kedalam lembah kehinaan, namun perasaan dan keinginan yang tidak terkontrol itulah 
yang mengarahkannya. Menjalankan syari at untuk menutupi kesalahan dengan harapan dosa dapat terampuni.

Perbedaan pemahaman terhadap agama menjadikan kualitas dalam menjalankan agaman juga berbeda. Mayoritas dari pemeluk agama adalah karena faktor keturunan, melaksanakan kewajiban beragama lebih banyak ditentukan karena melihat orang tua dan lingkungan. Dengan demikian lingkungan, baik lingkungan keluarga, nilai sosial maupun budaya masyarakat yang berkolaborasi menjadi komunikasi sosial akan dapat merubah atau bahkan mengombang-ambingkan pola kehidupan sosial masyarakat itu sundiri, jika tidak adanya kontrol dari diri sendiri. Oleh karenanya dibutuhkan kolaborasi positif yang mengarah pada bentuk komunikasi yang komunikatif.

Menurut Habermas, tindakan komunikatif terarah pada "saling pengertian" (verstandigung) dan "koordinasi hidup bersama", di mana setiap orang melaksanakan kebebasannya dengan mengakui dan menerima orang lain sebagai subyek yang bebas. Tindakan komunikatif seperti ini berada dalam situasi tindakan yang bersifat sosial sehingga tindakannya strategis, bukan tindakan yang instrumental dan berada dalam situasi yang bersifat non sosial. ${ }^{23}$

Dalam kontek komunikasi, komunikasi sesungguhnya juga merupakan suatu bentuk komunikasi dari "pengalaman kehidupan sosial" yang meliputi tentang nilai, norma, serta budaya. Jika kehidupan sosial dipahami sebagai dasar tindakan komunikatif, berarti hanya pada pengalaman kehidupan sosial-lah tindakan komunikatif dalam konteks komunikasi sosial menjadi mungkin, karena pengalaman kehidupan sosial yang sejati merupakan puncak kepenuhan hidup pribadi manusia.

Perubahan masyarakat sangat ditentukan oleh basis material ekonomi, politik dan sosial. Kemungkinan terjadinya distorsi dalam komunikasi, dan tidak tercapainya komunikasi yang saling pengertian, adalah terdapatnya pribadipribadi neurotik di antara pelaku komunikasi. Habermas menjelaskan individu yang tidak mengerti tindakannya sendiri, tidak bersumber dari kesadarannya sendiri, dan cenderung melakukan rasionalisasi. Individu neurotik tidak mengerti tindakannya sendiri, tindakannya itu yang berasal dan motif-motif yang terhalau dari kesadarannya. Ia diasingkan oleh bagian dirinya dari dirinya sendiri, maka kehadirannya terwujud dalam bentuk rasionalisasi. Rasionalisasi menyembunyikan kebenaran darinya, karena kelakuannya.

Menuju masyarakat komunikatif inilah komunikasi sosial bisa terwujud, walapun tatanan nilai budaya antar individu itu berbeda, namun dalam perbedaan itu sekaligus terdapat persamaannya. Dari pengertian perbedaan dan persamaan inilah, komunikasi sosial merupakan pertemuan hati dan pikiran

\footnotetext{
23 Jürgen Habermas, The Theory of Communicative Action, vol. I, trans. Thomas McCarthy, (Boston: Beacon Press, 1985), hlm. 285.
} 
antara nilai, norma dan budaya. Komunikasi ini jalan bersama menuju ke arah kebenaran, partnership tanpa ikatan dan tanpa maksud yang tersembunyi.

Komunikasi sosial semestinya menuntut kepada pesertanya sikap menghargai, seperti menghargai orang lain, mau mendengarkan pendapat orang lain, jujur, terbuka, dan bersedia untuk bekerjasama dengan orang lain. Sikap mental seperti ini terdapat pada para peserta komunikasi yang telah memiliki kesadaran moral otonom dan menganut nilai-nilai universal.

\section{Daftar Pustaka}

Adlan, Abdul Jabar, 1995, Dirasah Islamiyah, IAIN Sunan Ampel, Surabaya.

Al-Qur'an dan Terjemahan, Departemen Agama Republik Indonesia

Bellah, Robert N, 1992, Religi Tokugawa; Akar-Akar Budaya Jepang (terj) Wardah Hafidz dan Wiladi Budiharga, Gramedia Pustaka Utama, Jakarta.

David Krech, Richard S., and Egerton, 1996, Individual in Society, Mc. Graw Hill Kogakusha, Ltd. England.

Jürgen Habermas, 1985, The Theory of Communicative Action, vol. I, trans. Thomas McCarthy, Beacon Press, Boston.

Jürgen Habermas, 1990, Moral Consciousness and Communicative Action, trans. Christian Lenhardt dan Shierry Weber Nicholsen, Cambridge: The MIT Press, Massachussett.

Kartono, Kartini, 1991, Patologi Sosial, Rajawali Press, Jakarta.

Margono. S, 1997, Metode Penelitian Pendidikan, PT.Rineka Cipta Jakarta.

Michael, Patton Quinn, 1987, Qualitative Evolution Methods, Sage Publication, London.

Milles, Mattew B. dan.A. Michael Huberman, 1992, Analisis Data Kualitatif Penerbit:Universitas Indonesia, Jakarta.

Moleong. J. Lexy, 2002, Metodologi Penelitian Kualitatif, Cet.7, PT.Remaja Rosdakarya, Bandung.

Najati, Utsman, 2000, Al-Qur'an dan Ilmu Jiwa Agama, Penerbit Pustaka, Bandung.

Nata, Abudin, Metodologi Studi Islam, PT. Raja Grafindo Persada, Jakarta.

NicoSyukur Dister Ofm, 1988, Pengalaman dan Motivasi Beragama Kanisius, Jakarta. 
Rasyid, Sulaiman, 2000, Fiqh Islam, Cet.33, Sinar Baru Al-Gresindo Yogyakarta.

Simandjuntak B, 2001, Patologi Sosial, PT Gramdeia, Jakarta,

Ya`cub, Dahlan, 2003, Kamus Bahasa Indonesia Kontemporer, PT. Raja Grafindo Persada, Jakarta. 